\title{
Funding Bright Ideas in the Dark Continent
}

\author{
Kanayo Ogwu \\ London School of Commerce Chaucer House, London, United Kingdom
}

Elias Pimenidis

Department of Computer Science \& Creative Technologies, University of the West of England, Bristol, United Kingdom

\section{Eugene Kozlovski}

University of Wales Trinity Saint David, London, United Kingdom

\begin{abstract}
This work explores the potential of small businesses and entrepreneurs, in developing countries, and Nigeria more specifically, in exploring the opportunities offered by social media based crowdfunding.

The aim is to propose a framework for funding bright ideas that have the capacity to support economic growth in the African continent and create continuous employment and prosperity for its people. The means for achieving such a transformation is proposed here as social media based crowdfunding. Some variables identified in this study are also visible in some other parts of the world like Asia and South America, and thus, the solutions recommended here can be translated (with some minor adjustments) to such markets.

The research uses data taken from a range of fundraisers in the United Kingdom and Nigeria, to "determine the effects of social media as a crowdfunding platform for startups, particularly in the developing world".
\end{abstract}

\section{Keywords}

Crowdfunding, entrepreneurship, SMEs, fundraising, developing countries, social media.

\section{Introduction}

According to Banji (2017), the small and medium enterprise (SME) sector in developing countries faces an under-funding crisis. The major problem entrepreneurs and SMEs face in the developing world is access to much needed funding, required to help them start, scale or save their businesses (Gbandi \& Amissah, 2014). The African continent is often referred to as the dark continent, because of the slow pace of development in the region characterized by; little or no access to power, poor quality of life, poverty of wide strata of population, internal crises, religious intolerance, corruption, sickness and diseases. In addition to this, the very low internet penetration levels and high cost of access to the internet, has further made it difficult for people within the continent to tap into a global online marketplace.

Over the past four decades, the Dark Continent has struggled to put economic policies in place to foster development in every ramification. As a result, entire populations rely on a single source of economic resource for the sustenance of the very fabrics of society; In Nigeria it is oil, in Ghana it is gold, etc., while in the Western/developed nations, ideas executed brilliantly with technology have leveraged the dependence on national economic resources.

This paper presents the early phase of a research that seeks to explore novel approaches to crowdfunding as an alternative investment instrument for SMEs and entrepreneurs in the developing world. Access to a global network of potential online donors, can help bridge the gap between bright ideas and the required funding needed to propel such ideas into tangible success in the Dark Continent.

The remainder of the paper is structured as follows. Section 2 introduces crowdfunding in the developed and the developing world. Section 3 discusses related work, while section 4 provides an account of the methodology followed in this 
research. Section 5 is focused on the outcomes, whilst section 6 presents the concluding comments on this work.

\section{Crowdfunding}

\subsection{Crowdfunding in the developed world}

Gerber et al. (2012) defined social media based crowdfunding as the practice of raising small amounts of capital from a large number of people, usually over the Internet. Delivorias (2017) provides some useful information on the growth of the crowdfunding industry in Europe and illustrates that the concept of crowdfunding is a financial revolution in the developed world. Lehner (2013) emphasized the relevance of crowdfunding by describing the concept as a core driver of social capital for entrepreneurs in the developed world, which is evidenced by the fact that some analysts estimated the global crowdfunding industry to be worth $\$ 5.1$ billion in 2013 and $\$ 1.6$ billion in the USA alone in 2014 (Barnet, 2014). According to the world's leading crowdfunding research firm, Massolution (2015), and supported by analysis from sources such as Juniper (2016) and Barnett (2015), they expand the discussion on the growth of the crowdfunding industry by stating that the crowdfunding industry's growth in six years is phenomenal. According to their analysis, the industry reported $\$ 880$ million in 2010 , showing a relatively small market with minimal growth potential. In 2013, the industry reported $\$ 6.1$ billion and expanded by $167 \%$ to reach $\$ 16.2$ billion by the end of 2014 . The industry doubled the amount raised in 2014 to reach an astonishing $\$ 34.4$ billion in 2015 . The crowdfunding industry is growing at a tremendously fast pace in the developed world. Why the developing world is yet to embrace, encounter and benefit from this growing new financial phenomenon is largely unknown. However, this study reveals the key factors and variables that affect the ability and efficacy for social media based crowdfunding to take root in developing countries with emphasis on the African continent.

\subsection{Crowdfunding in the developing world: challenges and opportunities.}

An important barrier to innovation is the availability of early-stage funding (Cosh, Cumming \& Hughes, 2009). This school of thought is supported by Kuppuswamy and Bayus (2015) who state that "Given the difficulties that newly established ventures face in their attempt to attract fi- nancing from angel investors, banks and/or venture capital funds, some entrepreneurs are now tapping into large, online communities of consumer-investors called "crowdfunding".

Ariyo (1999) pointed out that one of the major problems in the developing world is the difficulty entrepreneurs and SMEs have to put up with, in order to obtain capital to fund their projects, ideas and or grow their businesses. The reason for this challenge can be attributed to the fact that most SMEs and indigenous entrepreneurs in the developing world are unable to provide collaterals to source for bank loans, neither do they have the privilege and access to venture capitalists or other influential and affluent family members who can bridge the gap between their ideas and the funding required to turn it into a profitable business venture. These factors make it almost impossible to secure funding for their businesses or ideas (Beck \& Kunt, 2006).

According to a statement issued by the Central bank of Nigeria (2017) small and medium enterprises (SMEs) are very critical to the development and growth of any economy as they possess great potentials for employment generation, output diversification, improvement of local technology, development of indigenous entrepreneurship and forward integration with large-scale industries. However, in Nigeria, there has been gross and visible under-performance of the SMEs sub-sector and this has largely undermined its contribution to economic growth and development. The CBN attributed this under-performance of the sector to a lack of funding for SMEs in the country. According to the (FSS 2020 SME Sector Report, 2017), key issues affecting the SMEs in the country can be placed in four categories namely: unfriendly business environment, poor funding, low managerial skills and a lack of access to modern technology. Amongst these, the shortage of finance occupies a very central position. In Nigeria for instance, the fragile economic environment and absence of requisite infrastructure has rendered SME practice costly and inefficient, thereby worsening their credit competitiveness. While the CBN has made yet another commitment to invest and/or approve the sum of N500 billion in debenture stock into the SME sector via the Bank of Industry (BOI) very little has changed. The problem of a lack of funding for SMEs in Nigeria has lasted over two decades.

As illustrated by Beck and Kunt (2006), most SMEs and indigenous entrepreneurs in the developing world are unable to provide collaterals to 
source for bank loans; neither do they have the privilege and access to venture capitalists or influential and affluent family members. Taiwo, Falohun and Agwu (2016) further confirms that SMEs are generally very susceptible, with a large number of SMEs shutting down due to difficulty in accessing credit facility and or loans from banks and other financial institutions. The Organisation for Economic Co-operation and Development, 2017) report only re-confirms the fact that SMEs are still struggling to access funding from lenders. They insinuate that access to credit facilities for SMEs and entrepreneurs has witnessed a sharpdownturn between 2015 and 2017 across several industries in many countries, especially developing nations. Whilst access to funding is the core factor that has made it difficult for SMEs and entrepreneurs to create meaningful value in developing countries, other factors such as: the low levels of internet penetration, low social media penetration, poverty of wide strata of population, high cost of internet access, fraud concerns, lack of adequate ICT infrastructure, poor online payment options and government policies towards crowdfunding has somewhat rendered the concept of crowdfunding as an alternative fundraising instrument inaccessible to SMEs and entrepreneurs in the markets in question.

These factors make it almost impossible for SMES and entrepreneurs to secure funding for their businesses and double as challenges to fundraising for SMEs and entrepreneurs in developing countries, particularly in Nigeria and most African countries.

\subsubsection{Barriers to crowdfunding adoption in the developing world}

The concept of crowdfunding is yet to be embraced and practiced in most developing nations, particularly in Nigeria, for a number of reasons. As exemplified in the preceding sections of this paper, some of the identified reasons are: government policies towards crowdfunding, the low levels of internet penetration, poor social media penetration in the region, poverty of wide strata of population, absence of adequate ICT infrastructure and online payment options, lack of knowledge about the concept and benefits of crowdfunding by both potential fundraisers and funders, fraud concerns, levels of technology maturity or immaturity, etc. These identified factors will ultimately decide the efficacy of a crowdfunding framework and the practice of crowdfunding as an alternative fundraising instrument in the region.

\subsubsection{Relationship between internet penetra- tion/adoption levels and online fundraising}

According to Mckinsey \& Company (2014), well over $60 \%$ of the world's population remains offline. Without a determined strong push to remove the crucial deterrents to internet adoption, very little may change. This analogy simply means that more than 4 billion people stand the risk of being left behind. If this is the reality of the situation, it means that all the potential for social media based crowdfunding or the ability to source for funds over the internet as illustrated by the World Bank (2013) research carried out by the information for development programme [Infodev] is completely lost to entrepreneurs and SMEs in the developing world. Crowdfunding as a concept cannot be actualized without the wide spread of internet access. Early research into the market this study focuses on shows that out of a population of a little over 173.3 million, only approximately $30 \%$ of Nigerians are online and or have the ability to go online, whilst approximately $70 \%$ from a total of over one billion Africans are offline. India, Latin America and many parts of China also have a tremendously high offline population. (Africapractice, 2014). The core reasons for the high offline population are; (i) the very low levels of internet penetration in the region, (ii) poverty of wide strata of population and (iii) an unreasonably high cost of internet access. Furthermore, those who go online spend only a few minutes on platforms like Facebook and Yahoo mail, and either $\log$ out to save data or run out of data altogether. While mobile phones are having a wider penetration in the region, contemporary literature has not shown how that development has impacted and influenced a wider internet usage/penetration in the region. 
Table 1 Barriers to Internet adoption

\begin{tabular}{|c|c|c|c|c|}
\hline \multirow{2}{*}{$\begin{array}{l}\text { Barriers } \\
\text { directly } \\
\text { affecting } \\
\text { consumers }\end{array}$} & Incentives & Low incomes and affordability & User capability & Infrastructure \\
\hline & $\begin{array}{l}\text { 1.Lack of awareness } \\
\text { of Internet Relevant } \\
\text { use cases } \\
\text { 2. Lack of relevant } \\
\text { (e.g., local, localized) } \\
\text { content and services } \\
\text { 3. Lack of cultural or } \\
\text { social acceptance }\end{array}$ & $\begin{array}{l}\text { 1. Low income or consumer } \\
\text { purchasing power } \\
\text { 2. Total cost of ownership for } \\
\text { device } \\
\text { 3. Cost of data plan } \\
\text { 4. Consumer taxes and fees (Note } \\
\text { that the Nigerian government just } \\
\text { complicated this further by } \\
\text { introducing taxes on consumer } \\
\text { internet data purchases) }\end{array}$ & $\begin{array}{l}\text { 2. Lack of language } \\
\text { literacy }\end{array}$ & $\begin{array}{l}\text { 1. Lack of mobile } \\
\text { Internet coverage or } \\
\text { network access }\end{array}$ \\
\hline $\begin{array}{l}\text { Root causes } \\
\text { (e.g. } \\
\text { providers, } \\
\text { government) } \\
\text { regulatory, } \\
\text { industrial) }\end{array}$ & $\begin{array}{l}\text { A. High content and } \\
\text { service provider } \\
\text { costs and business } \\
\text { model constraints } \\
\text { B. Low awareness or } \\
\text { interest from brands } \\
\text { and advertisers } \\
\text { C. Lack of a trusted } \\
\text { logistics and } \\
\text { payments system } \\
\text { D. Low ease of doing } \\
\text { business } \\
\text { E. Limited Internet } \\
\text { freedom and } \\
\text { information security }\end{array}$ & $\begin{array}{l}\text { A. Challenging national economic } \\
\text { environment } \\
\text { B. High device manufacturer costs } \\
\text { and business model constraints } \\
\text { C. High network operator costs } \\
\text { and business model constraints } \\
\text { D. High provider taxes and fees } \\
\text { E. Unfavourable market structure }\end{array}$ & $\begin{array}{l}\text { Under-resourced } \\
\text { educational system }\end{array}$ & $\begin{array}{l}\text { A. Limited access to } \\
\text { international } \\
\text { bandwidth } \\
\text { B. Underdeveloped } \\
\text { national core } \\
\text { network, backhaul, } \\
\text { and access } \\
\text { infrastructure } \\
\text { C. Limited spectrum } \\
\text { availability } \\
\text { D. Nationa ICT } \\
\text { strategy that does not } \\
\text { effectively address } \\
\text { issue of broadband } \\
\text { access } \\
\text { E. Under-resourced } \\
\text { infrastructure } \\
\text { development (e.g., } \\
\text { FDl limits) }\end{array}$ \\
\hline
\end{tabular}

Source: Literature review; expert interviews; McKinsey \& Company

(2014)

The above factors are the core deterrents to internet adoption and these factors are predominant in the developing world. Until these barriers are eliminated, internet adoption and ultimately crowdfunding practices will be impracticable in the region.

A Facebook study in 2015 reinforced the findings of McKinsey and Company (2014) by revealing that the three key factors that keep people offline are: lack of infrastructure, affordability, and lack of relevant content for people in their indigenous languages (Firstpost, 2015). A much neglected reason why people do not use the internet is because they are not aware of the internet.

A 2013 survey and report by IAMAI found that 69 percent of Indian survey respondents cited a lack of awareness of the Internet as a reason they were not online.This challenge also extends into urban centres as well, where 21 percent of the respondents in a 2011 survey of Ethiopian residents in Addis Ababa said they did not know what the Internet is. While the predominant reasons why most people are disenfranchised from the internet is attributed to lack of infrastructure, low income and affordability, poverty, lack of awareness or use cases of the internet, high access to internet enabled devices i.e. mobile phones and com- puters, high cost of data packages, digital literacy and language proficiency etc; a much neglected barrier is the absence of local content in native languages of the offline population. Chang (2015) illustrated that there are 7100 languages in use globally, while only $5 \%$ of such languages are represented on the internet today. To be exact, the English language represents over $60 \%$ of all websites and information on the internet while the vast majority (approximately $80 \%$ ) of online content is only available in 10 languages, which approximately only about 3 billion people speak as their first language. This means that many individuals across the globe are completely oblivious of the internet's potential or cannot use it since there is very little or no useful content in their native language.

The availability of relevant local content is a foremost incentive towards the spread of the internet and or massive global internet adoption. Crowdfunding cannot be global or beneficial when over 4.4 billion people are offline. Most of the offline populations come from the Dark Continent i.e. Africa and most parts of Asia. According to Luxton (2016) while writing on behalf of the world economic forum, presented findings that Rwanda, Kenya, Uganda, Ethiopia and South Sudan have a $67 \%$ offline population representing 75 million people, while Mckinsey \& Company (2014) identified that Nigeria has a $62 \%$ offline population representing 108 million people and a $38 \%$ Internet penetration level representing 65.3 million people. The predominant factors that deter this offline population from going online are: low internet penetration in the region, lack of adequate ICT Infrastructure, affordability, skills awareness and cultural acceptance, and local adoption and use. The key question here is, if majority of the population is offline in developing countries, who will fund the bright ideas in such environments? If the focal point of the concept of crowdfunding is to democratize access to capital, the very fact that a great number of potential fundraisers and crowd investors are disenfranchised from participating in a global online crowdfunding marketplace, renders the concept of crowdfunding as a failure.

\section{Related work}

Early studies into the reasons why the developed world is yet to embrace, practice and benefit from "Crowdfunding" as a concept are largely due to certain key factors and or variables that are predominant in such markets. According to Saxton and Wang (2014) owing to the broad diffusion of 
social networks, alongside the rapidly growing interest in online giving and the web-high outreach potential, more and more organizations are increasingly integrating social media into their fundraising efforts. Agrawal, Catalini and Goldfarb (2011) pointed out that crowdfunding activities have demonstrated to have a truly global presence through the means of specialized social media fundraising platforms like Kickstarter and Indiegogo. Drury and Stott (2011) illustrated how the widespread internet access benchmarked by fundraising social networking platforms and driven by the emancipation of the crowd, propose new opportunities for entrepreneurs to gain startup capital via a crowdfunding process. While the above situations and analogies are generally acceptable realities, which led Zheng, Dahui, Jing and Yun (2014) to conclude that the popular practice of crowdfunding has drawn the attention of the research community; what was left out in the discussion is the fact that contemporary literature does not discuss how to apply such systems in the context of developing countries with lower internet penetration, energized by factors such as the absence of infrastructure, high internet access prices, illiteracy, low income and affordability, digital illiteracy and language proficiency, poverty of wide strata of population, poor ICT infrastructure, etc. Consequently, the potential of the application of social media based crowdfunding models in developing countries is unclear. Hence, there is still scope to investigate the various models of crowdfunding through social media in the context of developing economies, as a means of energizing entrepreneurship and the funding of bright and brilliant ideas that could boomerang into economic growth and prosperity in the Dark Continent.

Whilst scholars and authorities in the field of crowdfunding lay claim that the concept has "democratized access to capital" on a global scale, as emphasized by Keongtae and Hann (2014), the question is: has access to capital really been democratized on a global scale?

According to findings from researches carried out by Greenstone and Mas (2012) and by Laderman and Reid (2010), it was evident that providing small businesses with much needed capital has become more crucial in recent times and crowdfunding has been viewed as a viable alternative for raising such needed capital.

According to several studies carried out by Agrawal, Catalini and Goldfarb (2010), Keongtae and Hann (2014), Belleflamme, Lambert and
Schwienbacher (2014), and Keongtae and Viswanathan (2014), on the subject of crowdfunding, one key theme that is continuously eminent is the fact that the entire concept of crowdfunding is to democratize access to capital by making it possible for small businesses, entrepreneurs and inventors who have little or no access to funding and/or means of accessing such funds from other traditional methodologies like banks via loans, from investors in the form of seed funds or from influential families and personalities to reach out to an eager crowd and secure funding over the internet for their projects. Thus, as observed by Keongtae and Viswanathan (2014), entrepreneurs usually become financially disadvantaged because of several factors such as their age, race, educational background, and/or social groups, which ultimately hinders their ability to secure funding for their projects.

Keongtae and Hann (2014) explained that crowdfunding as a concept can only be viewed as being successful if it provides a new channel of capital to entrepreneurs who have very promising ideas, but are having difficulties in raising money from conventional funding sources irrespective of the geographical locations of such entrepreneurs.

Most researchers approach this question from a myopic and outright bias perspective. It is possible for a few researchers to lay claim that the question of crowdfunding's potential to democratize access to capital has been answered and proved by taking selective statistics from the global crowdfunding industry growth and numerous success stories put forth by successful fundraisers. If the concept of crowdfunding and its practice is still alien and non-applicable in developing countries like Nigeria, Cameroon, Ghana, Botswana, Zimbabwe, Congo Brazzaville, Kenya, etc, then the opportunity to raise funding for their creative projects from the crowd, is lost to the millions of entrepreneurs, indigenous business practitioners and small-scale businesses in such regions. If the enablement of web 2.0 technology or later is non-existent or adequately harnessed to provide a new fundraising instrument to entrepreneurs in such regions who are trapped in the traditional methods to accessing capital with over $90 \%$ of them completely credit unworthy; then the concept of crowdfunding can be said to be a failure. This is a difficult analogy for many crowdfunding theorists to accept in the developed world; however, the findings of this paper show that the concept of crowdfunding is still alien in the Dark Continent whilst an abundance of bright business 
ideas exists in the region. At the same time, little focus has been put by the existing studies on utilizing social media platforms as well as coupling them with off-line strategies for unleashing the potential of crowdfunding in the developing world.

\section{Methodology}

Due to the absence of significant previous work in the area of social media based crowdfunding in the developing countries, this research has adopted an exploratory approach. The design of the study was based on an interpretative paradigm and qualitative analysis (Merriam, 1998, p. 15). In accordance with this method, 20 fundraisers in the United Kingdom were selected to participate in the study followed by another 20 fundraisers in Nigeria. The purposive sampling technique has been used for the data collection (Saunders, Lewis, \& Thornhill, 2012). The UK based fundraisers were selected first in order to understand typical challenges associated with online fundraising in the developed world, and then the Nigerian fundraisers were approached next in an attempt to understand why the fundraisers in developing countries cannot embrace the models of crowdfunding practiced in the UK. At the end of the qualitative study, certain key themes were identified which helped in developing a set of research propositions.

Data collection adopted in-depth interviews via use of questionnaires with open-ended questions and a few closed ended questions. This approach ensured that the interviews were structured thus yielding a straightforward thematic analysis and identification of common patterns in fundraisers opinions.

\section{Research outcomes}

\subsection{Key themes}

The thematic analysis of the interviews has resulted in a number of key themes identified for both the UK and Nigerian participants. These are compared in Table 2.
Table 2 Identified key themes from the qualitative study.

\begin{tabular}{|l|l|}
\hline $\begin{array}{c}\text { Key Themes by the UK } \\
\text { participants }\end{array}$ & \multicolumn{1}{|c|}{$\begin{array}{c}\text { Key themes by the Nigerian } \\
\text { participants }\end{array}$} \\
\hline Economic prosperity & $\begin{array}{l}\text { Poverty of wide strata of } \\
\text { population }\end{array}$ \\
\hline $\begin{array}{l}\text { High levels of social } \\
\text { media penetration }\end{array}$ & $\begin{array}{l}\text { Low levels of social media } \\
\text { penetration }\end{array}$ \\
\hline $\begin{array}{l}\text { Technology maturity and } \\
\text { adequate online payment } \\
\text { options }\end{array}$ & $\begin{array}{l}\text { Poor online payment options } \\
\text { energised by technological } \\
\text { immaturity. }\end{array}$ \\
\hline $\begin{array}{l}\text { High levels of Internet } \\
\text { penetration }\end{array}$ & $\begin{array}{l}\text { Low levels of internet } \\
\text { penetration }\end{array}$ \\
\hline $\begin{array}{l}\text { Low levels of fraud } \\
\text { concerns and } \\
\text { associated risks }\end{array}$ & $\begin{array}{l}\text { Very high levels of fraud } \\
\text { concerns and risks }\end{array}$ \\
\hline $\begin{array}{l}\text { Low cost associated with } \\
\text { internet access }\end{array}$ & $\begin{array}{l}\text { High costs associated with } \\
\text { internet access and data plan } \\
\text { packages }\end{array}$ \\
\hline
\end{tabular}

Source: The authors

\subsection{Constructs associated with the crowdfunding framework}

This work has identified four key variables that affect the practicability and or efficacy of establishing a crowdfunding framework and/or model in developing countries. While these four key variables will be discussed briefly in this section, further research is intended for carrying out a comprehensive empirical study, where the identified factors will be introduced into contemporary crowdfunding literature and investigated using standard research frameworks. These factors are:

1. Level of internet penetration. Over $70 \%$ of Nigerians do not have access to the internet due to poor infrastructure, high cost of internet access, low incomes and affordability and poverty of wide strata of population. Those who live in rural areas are completely disenfranchised and have never used the internet for once. The researcher proposes a nation-wide internet adoption policy with strategic steps towards its achievement.

2. Level of social media penetration. Surprisingly, Facebook released data in 2016 revealing that only 30 million Nigerians had accounts with the giant social network whilst the remaining 143.3 million Nigerians are yet to get involved with social media. This can be attributed to the fact that there is a lack of internet access and a general nonchalant attitude towards utilizing social media and or social networking platforms which is a predominant factor that keeps the remaining 143 million Nigerians away from the internet. According to Shane and Cable, (2002), Wasko and Faraj (2005) and Saxton and Wang 
(2014), social network ties are the number one factor that leads to a successful crowdfunding effort. The data in this study also re-enforces and validates that point. The poor social media penetration in the developing world is another reason why most online fundraising activities results to failure as fundraisers are unable to take advantage of the social network effect.

3. Levels of technological penetration/maturity and the number of online payment options available. Technology advancement is the greatest revolution of the $21^{\text {st }}$ century and nothing can be achieved without designing, developing and deploying suitable technology. The lack of online payment structures like Paypal, Stripe, etc in the region energized by the poor ICT infrastructure in most parts of the developing world has made it difficult for many banks to facilitate easy overthe-net payments for its users, whilst making it difficult for fundraisers and donors/crowdfunding platforms to harness the power and potential of web 2.0 technology, which snowballs into making contributions over the internet near impossible. Online and or social media based crowdfunding cannot be actualized in the region until online payment structures are fully functional.

4. Poverty of wide strata of population. If both the founders and funders are living below the poverty line, where will donations come from? We must re-open the discussion about the elimination of poverty by creating employment and conducive environments for people to earn a decent living before crowdfunding can be actualized in most parts of the developing world.

\subsection{Research propositions}

The research indicates that the presence of the aforementioned factors in the developing world, are the primary reasons why; i) the concept of crowdfunding has not been encountered and embraced in the developing world, ii) the current models of crowdfunding in the developed world cannot be translated to developing context. Any crowdfunding model and or framework proposed for developing countries must take these factors into consideration.

Furthermore, the following propositions can be made.

- The evidence gathered indicates that the levels of internet penetration are having a negative impact on crowdfunding in Nigeria
- The evidence gathered indicates that the levels of social media penetration are having a negative impact on crowdfunding in Nigeria

- The evidence gathered showed that where there is a high level of technological penetration, there is a parallel high level of online payment options and vis a vis.

- The evidence gathered revealed that the higher the level of poverty, the lower the fundraising in a fundraising environment, and vis-a vis.

\section{Conclusions}

Social networking platforms have facilitated new ways of raising and giving money and, in turn, brought changes to the set of factors associated with success in raising funding for entrepreneurs. However, the study reveals that the concept of crowdfunding is still alien in developing nations. Nigeria was used as the focal point in this study because it is the most populous country in Africa. If crowdfunding can be non-existent in the region, how much more in smaller countries with worse cases of internet penetration and wider stratification of poverty amongst its population.

The current models of crowdfunding practiced in the United Kingdom and by extension, in the developed world, cannot be translated into a developing world context and/or market.

Variables such as: the low levels of internet penetration, low levels of social media penetration, poverty of wide strata of population, levels of fraud concerns, and poor technology penetration, i.e. lack of ICT infrastructure and minimal/non-existent internet based payment options, are the core barriers that affect the introduction and efficacy of crowdfunding practices in developing countries.

Whilst the above factors have a significant impact on crowdfunding in the markets in question, an independent model that combines an offline and online fundraising framework, is most likely to be effective in developing countries, despite the visible presence of the factors that pose as challenges to crowdfunding in the region. A formulation and evaluation of such a framework represents a direction for future research in this area.sm 


\section{References}

World bank, (2013, October 24). Crowdfunding's Potential for the Developing World. Retrieved September 9, 2014, from https://www.infodev.org/infodevfiles/wb_crowdfundingreport-v12.pdf

Africapractice, (2014). The social media landscape in Nigeria: the who, the what and the know. Retrieved December 20, 2014, from http://www.africapractice.com/wpcontent/uploads/2014/04/Africa-Practice-Social-MediaLandscape-Vol-1.pdf

Agrawal, A. K., Catalini, C., \& Goldfarb, A. (2011). The Geography of Crowdfunding. National Bureau of Economic Research, Working Paper No. w16820. Retrieved January 15, 2017, from http://www.nber.org/papers/w16820

Ariyo, D. (1999). Small firms are the backbone of the Nigerian economy. Africa Economic Analysis, Africa Business Information Services, Bridgnorth United Kingdom.

Banji, O.O. (2017) SME: Issues, Challenges and Prospects. Financial System Strategy 2020 Report 2017. Retrieved March 22, 2016, from https://www.cbn.gov.ng/fss/wed/SME_Issues, \%20Chall enges $\% 20$ and $\% 20$ Prospects_Oyeyinka\%20Banji.pdf

Barnett, C. (2015) Trends Show Crowdfunding to Surpass VC In 2016, Forbes online Magazine. Retrieved June 9, 2015, from

https://www.forbes.com/sites/chancebarnett/2015/06/09 /trends-show-crowdfunding-to-surpass-vc-in2016/2/\#19103001666f.

Beck, T. \& Kunt, A. D. (2006). Small and medium-size enterprises: Access to finance as a growth constraint. Journal of Banking \& Finance, 30 (11), 2931-2943.

Belleflamme, P., Lambert, T., \& Schwienbacher, A. (2014b): Crowdfunding: Tapping the Right Crowd. Journal of Business Venturing, 29 (5), 585-609.

Chang, L. (2015). On the Web right now? You're in the minority: most people still don't have Internet, Digitaltrends.com, online. Retrieved February 15, 2017, from https://www.digitaltrends.com/web/4-billion-people-lackinternet-access/

Central Bank of Nigeria (2017). SME Finance. Retrieved April 24, 2017, from https://www.cbn.gov.ng/devfin/smefinance.asp,

Cosh, A., Cumming, D., \& Hughes, A. (2009), Outside Entrepreneurial Capital. The Economic Journal, 119 (540), 1494-1533.

Delivorias, A. (2017). Crowdfunding in Europe: Introduction and State of Play. Retrieved January 1, 2017, from http://www.europarl.europa.eu/RegData/etudes/BRIE/2 017/595882/EPRS BRI(2017)595882 EN.pdf

Drury, J., \& Stott, C. (2011). Contextualising the Crowd in Contemporary Social Science. Contemporary Social Science, 6 (3), 275-288.

Firstpost (2015, February). Most people in developing countries have no Internet access: Facebook. Retrieved February 12, 2015, from http://tech.firstpost.com/newsanalysis/most-people-in-developing-countries-have-nointernet-access-facebook-256125.html

Gbandi, E. C., \& Amissah, G. (2014). Financing Options for Small and Medium Enterprises (SME's) In Nigeria. European Scientific Journal, 10 (1), 327-340.

Greenstone, M., \& Mas, A. (2012). Do Credit Market Shocks Affect the Real Economy? Quasi-Experimental Evidence from the Great Recession and Normal
Economic Times. Retrieved September 9, 2014, from http://economics.mit.edu/files/10237

Kuppuswamy, V., \& Bayus, B. L. (2015). Crowdfunding Creative Ideas: The Dynamics of Project backers in Kickstarter. Retrieved October 2, 2015, from https://funginstitute.berkeley.edu/wp-

con-

tent/uploads/2013/11/Crowdfunding_Creative_Ideas.pdf

Keongtae, K.T \& Viswanathan, S. (2014). The experts in the crowd: The role of reputable investors in a crowdfunding market. A paper presented at the workshop on information systems and economics, New Zealand.

Keongtae, K., \& Hann, I. H. (2014). The transformational role of IT in entrepreneurship: Crowdfunding and the democratization of access to capital and investment opportunity. Retrieved November 25, 2017, from https://pdfs.semanticscholar.org/90c3/e466cbbc8d936c 524f13c0dadf9fc0828de2.pdf

Laderman, E. \& Reid, C. (2008). Lending in Low- and Moderate-Income Neighbourhoods in California: The Performance of CRA Lending During the Subprime Meltdown. Unpublished paper, economic research and community development department, Federal bank of San-Francisco, USA.

Lehner, M. O. (2013). Crowdfunding social ventures: a model and research agenda. Venture Capital, An International Journal of Entrepreneurial Finance, 15 (4), 289-311, doi: 10.1080/13691066.2013.782624.

Luxton, E. (2016). 4 billion people still don't have internet access. Here's how to connect them. Retrieved March 4, 2017, from

https://www.weforum.org/agenda/2016/05/4-billionpeople-still-don-t-have-internet-access-here-s-how-toconnect-them/

Massolution (2015, March 31). Crowdfunding annual Industry Report 2015. Retrieved August 31, 2015, from http://reports.crowdsourcing.org/index.php?route=produ ct/product\&path=0\&product_id=54

Mckinsey \& Company (2014, October). Offline and Falling Behind; Barriers to Internet Adoption. Retrieved January 10,2016 , from

http://www.mckinsey.com/industries/high-tech/ourinsights/offline-and-falling-behind-barriers-to-internetadoption

Merriam, S. B. (1998). Qualitative Research and Case Study Applications in Education, $\left(2^{\text {nd }}\right.$ ed.). San Francisco: Josey-Bass.

Organisation for Economic Co-operation and Development (2017). Financing SMEs and Entrepreneurs 2017: AN OECD SCOREBOARD. Retrieved May 16, 2017, from https://www.oecd.org/cfe/smes/Financing\%20SMEs\%2 0and\%20Entrepreneurs\%202017_Highlights.pdf

Saxton, G. D., \& Wang, L. (2014). The Social Network Effect: The Determinants of Giving Through Social Media. Nonprofit and Voluntary Sector Quarterly, 43 (5) 850 868.

Saunders, M., Lewis, P. \& Thornhill, A. (2012). Research Methods for Business Students $\left(6^{\text {th }}\right.$ ed.). Harlow: Pearson Education Limited.

Shane, S., \& Cable, D. (2002). Network ties, reputation, and the financing of new ventures. Management Science, 48 (3), pp. 364-381.

Taiwo, J. N., Falohun, T. O., \& Agwu, M. E. (2016). SMEs Financing and its effects on Nigerian Economic Growth. European Journal of Business, Economics and Accountancy, 4 (4), 37-54. 
Wasko, M. M. \& Faraj, S. (2005). Why Should I Share? Examining social capital and knowledge contribution in electronic networks of practice. MIS Quarterly, 29 (1), Special Issue on Information Technologies and Knowledge Management (Mar. 2005) 35-57.
Zheng, H., Dahui, L., Jing, W., \& Yun, X. (2014). The role of multidimensional social capital in crowdfunding: A comparative study in China and US. Journal of Information \& Management, 51 (2014), 488-496.

\section{$\bowtie$ Correspondence}

\section{Kanayo Ogwu}

London School of Commerce Chaucer House

White Hart Yard, London SE1 1NX, United Kingdom

E-mail: kanayoogwu@yahoo.com 